\title{
純水中にわける鉄鋼材料の腐食に及ぼす温度の影響*
}

\author{
本田卓**, 樫村栄二**, 大橋健也**, 古谷保正**

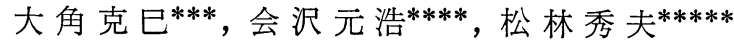 \\ ** 株式会社日立製作所日立研究所 \\ *** 株式会社日立製作所日立工場 \\ $* * * *$ 日立エンジニアリング株式会社 \\ $* * * * *$ 中国電力株式会社
}

\section{Effect of Temperature on Corrosion of Steels in High Purity Water*}

\author{
Takashi Honda** Eiji Kashimura** Kenya Ohashi** Yasumasa Furutani** \\ Katsumi Ohsumi*** Motohiro Aizawa**** and Hideo Matsubayashi***** \\ **Hitachi, Ltd., Hitachi Research Laboratory \\ ***Hitachi, Ltd., Hitachi Works \\ ****Hitachi Engineering Co., Ltd. \\ *****The Chugoku Electric Power Company, Inc.
}

\begin{abstract}
Effect of temperature on corrosion behavior of steels was evaluated in the range of 150$300^{\circ} \mathrm{C}$ in high purity water containing about $200 \mathrm{ppb}$ oxygen. The exposure tests were carried out in actual and simulated reactor water of BWR plants. Through X-ray diffractometry, SIMS, XPS and chemical analyses, it was clarified that the chemical composition and morphology of oxide films formed on austenitic stainless steel changed above about $250^{\circ} \mathrm{C}$. Chromium dissolved easily through corrosion above this temperature, and the oxide films primarily consisted of spinel type oxides containing high concentration of nickel. Further, as the protectivety of oxide films increased with temperature, the corrosion rate had a peak around $250^{\circ} \mathrm{C}$ after a long exposure period. A major phase of oxide films on carbon steel was magnetite in the whole temperature range. However, as the oxide films formed at high temperatures had very compact structures, the effect of temperature on the corrosion rate was similar to that observed on stainless steel.
\end{abstract}

Key words: BWR type reactors, stainless steels, carbon steels, general corrosion, temperature, demineralized water, oxide films

\section{1. 緒言}

沸騰水型原子炉 $(\mathrm{BWR})$ に和ける鉄鋼材料の腐食とそ

* 第 32 回腐食防食討論会 (於北海道大学) で発表

** 干317 茨城県日立市久慈町 4026 (4026, Kuji-cho, Hitachi-shi, Ibaraki-ken, 319-12 Japan)

*** 于317 茨城県日立市幸町 3-1-1 (3-1-1, Saiwaicho, Hitachi-shi, Ibaraki-ken, 317 Japan)

**** 7317 茨城県日立市幸町 3-2-1 (3-2-1, Saiwaicho, Hitachi-shi, Ibaraki-ken, 317 Japan)

***** 7730 広島県広島市中区小町 4 番 33 号 (4-33, Komachi, Naka-ku, Hiroshima-shi, Hiroshimaken, 730 Japan)
れにともなら ${ }^{60} \mathrm{Co}$ 等の放射性イオンの蓄積に関しては 種々の観点から研究が行われ1) 5), 挙動が明らかにされ つつある。しかし, 炉水環境の影響等で不明な点も多い。 前報尚ではプラントの定常運転状態である $288^{\circ} \mathrm{C}$ に特け る 304 鋼と炭素鋼の腐食並びに蓄積挙動について検討し た。しかし，プラントでは場所による温度分布や起動， 停止にともなら温度変化があり, 腐食に対する温度の影 響を明らかにする必要がある。純水中に和汁る影響につ いては，すでにいくつかの報告がある。たと竞ば，ステ ンレス鋼では溶存酸素濃度 (DO) が比較的低い場合に， 腐食速度がある温度で極大を示す現象が, Warzee ${ }^{7)}$, 前 
$川^{8)}$, 伊藤9)らによって報告されている。この温度は鋼 種, DO あるいは表面状態等により異なっているようだ が，いずれの場合も $200^{\circ} \mathrm{C}$ 以上の高温である。一方， Brush ら ${ }^{100}$ によると, 炭素鋼では $100^{\circ} \mathrm{C}$ 付近に極大点 がある。こうした挙動は腐食に対する酸化皮膜の保護性 に起因するものと考光られるが，皮膜関しての検討は 不十分で, 現象の解明には至っていない。また, ${ }^{60} \mathrm{Co} の$ 蓄積に及ぼす温度の影響は, 304 鋼を対象に筆者ら ${ }^{1)}$ が 実炬水を用いて $130 \sim 240^{\circ} \mathrm{C}$ の範囲で検討したのみで, 高温領域での検討が抜けている。

そこで, 本報では DO $200 \mathrm{ppb}$ の純水中に和ける 304 鋼と炭素鋼の腐食挙動及び皮膜形態の温度による変化を $150 \sim 300^{\circ} \mathrm{C}$ の範囲で検討するとともに, $130 \sim 280^{\circ} \mathrm{C}$ の 実炉水中に長期間浸漬した 304 鋼及び $316 \mathrm{~L}$ 鋼への ${ }^{80} \mathrm{Co}$ 蓄積挙動を酸化皮膜に着目して検討した。

\section{2. 実験方法}

\section{1 模擬炉水浸清実験}

実験には前報的と同じ装置を用いた。本装置は水質調 整タンク，給水タンク，オートクレーブ及び水質測定部 より構成されて拈り, 温度は再生熱交換器, 予熱器によ り $150 \sim 300^{\circ} \mathrm{C}$ に保持した。DO は酸素-窒素混合ガス を用いて $200 \pm 10 \mathrm{ppb}$ に調整した。供試材には 304 鋼 及び炭素鋼を用いたが，その化学組成及び加工法は前 報曰)に述べた。浸漬は $90 \mathrm{~h}$ 行い, 生成した酸化皮膜に対 乙て重量測定並びに走查型電子顕微鏡 (SEM), X 線回 折 (XRD), 二次イオン質量分析 (SIMS) 及びX線光電子 分光 (XPS) による分析を実施した。酸化皮膜は $0.5 \mathrm{wt} \%$ ヘキサメチレンテトラミンを含む $5 \mathrm{wt} \%$ 硫酸水溶液中 で，試験片を陰極に，白金線を陽極にして，70 ${ }^{\circ} \mathrm{C}$, 電流 密度 $20 \mathrm{~A} / \mathrm{dm}^{2}$ で $30 \sim 60 \mathrm{~s}$ 電気分解して金属母材より剝 離し, 皮膜剥離前後の試験片の重量差から皮膜量を求め た。また，腐食減量は浸漬前と浸漬後に皮膜を剥離した のちの試験片の重量差から, 放出量 ${ }^{8)}$ は腐食減量と皮膜 中の金属元素量との差から求めた。な㥂, SIMS 及び XPS の測定条件は前報礼詳述した。

\section{2 実炉水浸清実験}

実炬に打いて，炉水浄化系上り分岐した炉水を用い， 304 鋼の浸漬実験を実施した。用いた試験片の化学組成 と加工法は前報1) 飞述べた。試験片を装着するホールダ は, 炉水の流れ方向に直列に 6 個を配置した。炉水水質 は本装置の入口で測定し, 水質变化が無くなった時点か ら浸漬を開始した。炉水中の放射性核種及び金属元素の 濃度は前報1)に示した。 ${ }^{80} \mathrm{Co}$ 濃度は $100 \mu \mathrm{Ci} / \mathrm{m}^{3}$ で $98 \%$ 以上がイオンとして存在し, 鉄クラッド濃度は $1 \mathrm{ppb}$ 以 下であった。温度はホールダごとに表面温度計を用いて 測定した。上流から下流にかけて温度下降がみられ，
$130 \sim 240^{\circ} \mathrm{C}$ の範囲にあった。炉水の DO は 160 170 $\mathrm{ppb}$, 比電導度は $0.10 \sim 0.12 \mu \mathrm{S} / \mathrm{cm}, \mathrm{pH}$ は $6.9 \sim 7.2$, 流速は $0.5 \mathrm{~m} / \mathrm{s}$ であった。試験片の浸漬は各温度で $100 \sim 1,900 \mathrm{~h}$ 行い, ${ }^{80} \mathrm{Co}$ 蓄積量を $\mathrm{Ge}(\mathrm{Li})$ 半導体検出 器で測定した。ぬた, 前述したカソード電解法により酸 化皮膜を剥離，定量した。皮膜量は含まれる金属元素 (鉄,クロム, ニッケル) の総量から求めた。

次に, 実験終了後, 本装置とプラントを結ぶ配管の一 部を切り出し，内面に形成した皮膜の分析を行った。こ の配管 (内径 $25 \mathrm{~mm}$, 長さ $26.3 \mathrm{~m}$ ) は $316 \mathrm{~L}$ 鋼製で, 炉 水に $6,000 \mathrm{~h}$ さらされていた。試験片は温度が 250,265 及び $280^{\circ} \mathrm{C}$ の 3 箇所の配管を長さ $35 \mathrm{~mm}$ に切断後, 縦 に四分割したものを用いた。採取した試験片は ${ }^{80} \mathrm{Co}$ 蓄 積量を測定するとともに，XRD により酸化皮膜の形態 分析を行った。その後, 皮膜を剥離し, 皮膜中の鉄, ク ロム及びニッケルを定量した。

\section{3. 結 果}

\section{1 模擬忓水中での温度依存性（短期）}

Fig. 1 は 304 鋼を $150 \sim 300^{\circ} \mathrm{C}$ 飞拈いて, DO $200 \mathrm{ppb}$ の純水中に $90 \mathrm{~h}$ 浸漬した場合の腐食減量, 酸化皮膜量 及び放出量の温度依存性である。腐食反応に係った金属 の $80 \%$ 以上は皮膜として残った。いずれの量も温度の 上昇にともなって増加する傾向があり，とくに $250^{\circ} \mathrm{C}$ 以上において増加が著しかった。Fig. 2 は異なる温度で 形成した酸化皮膜のSEM とよる観察結果である。酸化

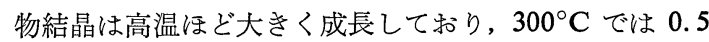
$\mu \mathrm{m}$ 程度の均一な粒径の結晶が表面を一様に扮扮ってい た。

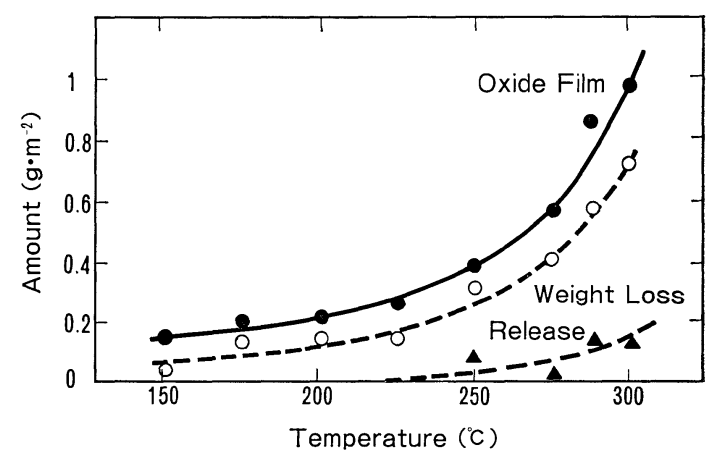

Fig. 1 Effect of temperature on corrosion behavior of Type 304 stainless steel exposed for $90 \mathrm{~h}$.

次に, 酸化皮膜中のクロムとニッケルの分布を SIMS で調べた。結果を Fig. 3 亿示す。約 $250^{\circ} \mathrm{C}$ を境に, こ の 2 元素の分布に差がみられる。 $250^{\circ} \mathrm{C}$ 以上で形成した 皮膜では, クロム濃度は皮膜の表面方向に単調に減少し 


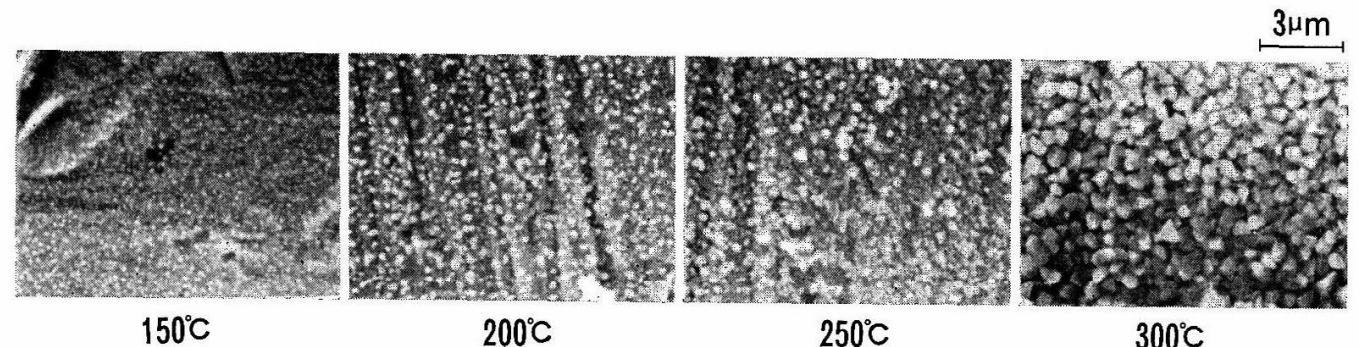

Fig. 2 Scanning elcctron micrographs of oxide films formed on Type 304 stainless steel exposed at different temperatures for $90 \mathrm{~h}$.
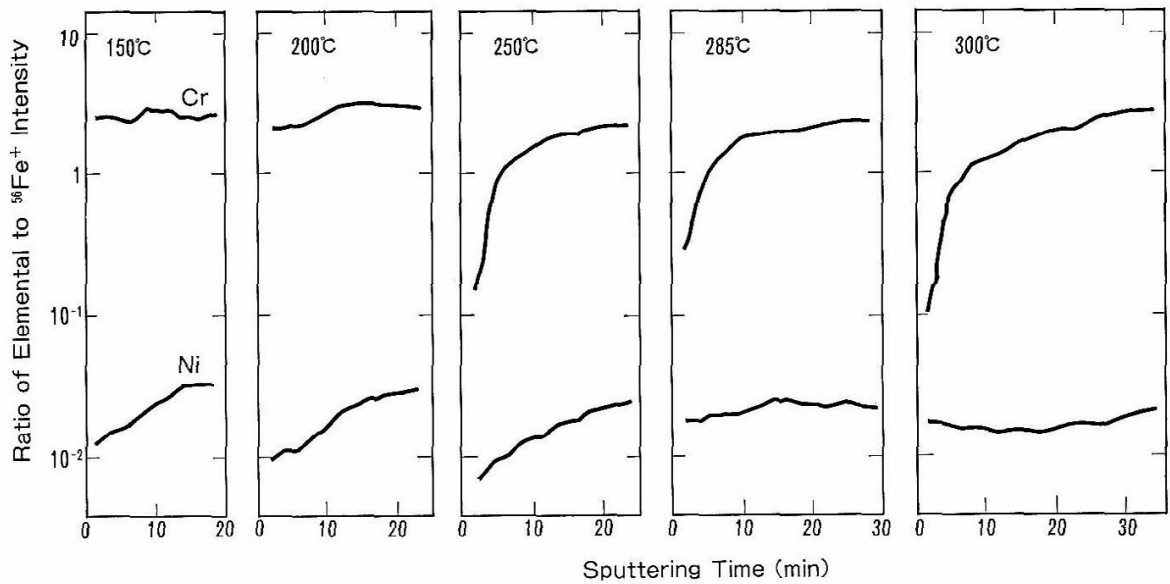

Fig. 3 Depth concentration profiles of elemental $\mathrm{Cr}$ and $\mathrm{Ni}$ in oxide films formed on Type 304 stainless steel exposed at different temperatures for $90 \mathrm{~h}$.

て扣り，腐食にともなってクロムが溶出したことを示し ている。一方,ニッケルは高温では皮膜中に安定に存在 し，低温で溶出する傾向にある。Fig. 4 はXPSにより 皮膜最外表面に叔ける鉄とクロムの存在形態を調べた結 果である。Fe2p $p_{3 / 2}$ のスペクトルは，いずれの温度に就 いても $712 \mathrm{eV}$ 付近にピークを示した。Cr $2 \mathrm{p}_{3 / 2}$ のピー クは $577 \mathrm{eV}$ 付近にあったが, ピーク強度は高温で低下 した。な拉，湘定エネルギーは Cls の結合エネルギーを $285.0 \mathrm{eV}$ として補正した。なお， Ni $2 \mathrm{p}_{3 / 2}$ は計数感度が 覀く、明膫なピークが得られなかったので図示しなかっ た。一方, Fig. 5 は Ols スペクトルを $\mathrm{H}_{2} \mathrm{O}$ (533.0 $\mathrm{eV})^{11)}, \mathrm{OH}^{-}(531.6 \mathrm{eV})^{11)}$ 及び $\mathrm{O}^{2-}(530.3 \mathrm{eV})^{11)}$ にピー ク分離し、それぞれのピーク強度の温度変化を示した眓 である。 $\mathrm{H}_{2} \mathrm{O}$ の存在比率注温度によらず一定でが，温度 上昇にともない $\mathrm{O}^{2-}$ 基の存在比率は增し, $\mathrm{OH}^{-}$基は減 少する傾问を示した。

次に, 炭素鋼の腐食举動と温度との関係を調べた。 Fig. 6 は腐食娍量と酸化皮膜量がともに $200^{\circ} \mathrm{C}$ に極小 值をもら，この温度を境に低温側，高温側いずれにおい ても増加する傾向があることを示している。また，放出

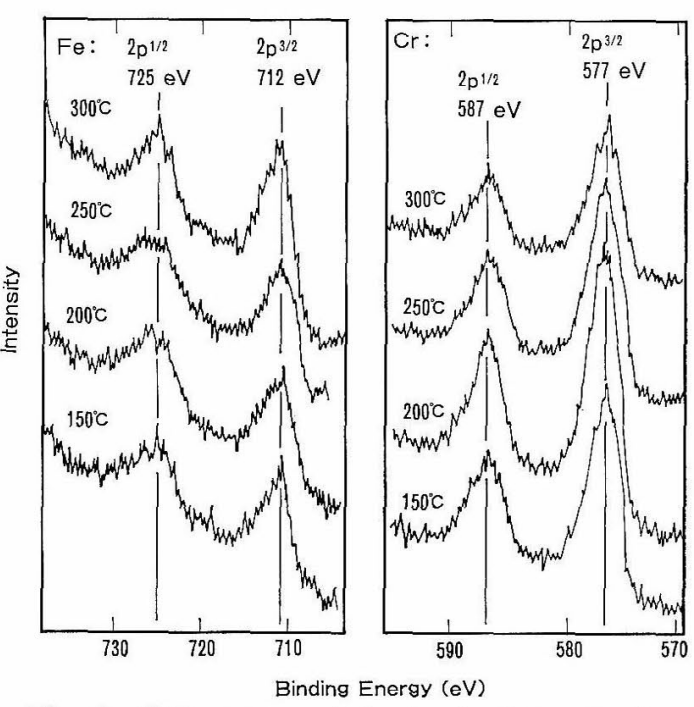

Fig. 4 XPS spectra of $2 p$ level of $\mathrm{Fe}, \mathrm{Cr}$ for oxide films formed on Type 304 stainless steel exposed at different temperatures for $90 \mathrm{~h}$. 


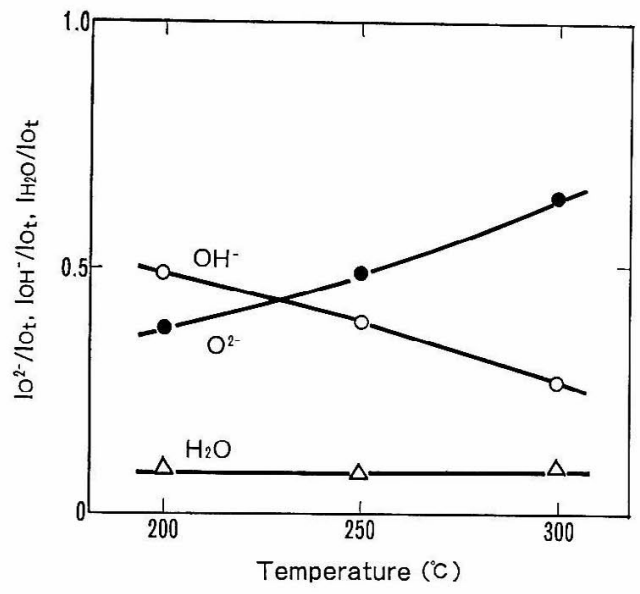

Fig. 5 Relative intensity of XPS signals for oxygen in oxide films on Type 304 stainless steel exposed at different temperatures for $90 \mathrm{~h}$.

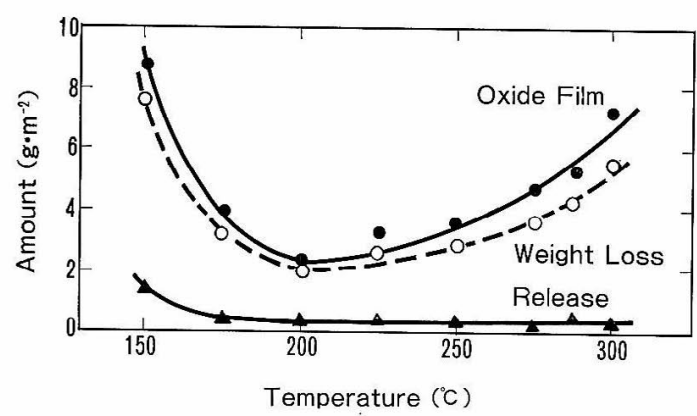

Fig. 6 Effect of temperature on corrosion behavior of carbon steel exposed for $90 \mathrm{~h}$.

量は $150^{\circ} \mathrm{C}$ で大きいが, $175^{\circ} \mathrm{C}$ 以上では温度依存性が

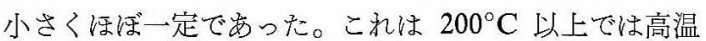
ほど皮膜の生成率が高いことを示している。Fig. 7 は SEM による皮膜観察の結果である。150 $\mathrm{C}$ で形成した 皮膜は酸化物結晶の粒佳が $2 \sim 3 \mu \mathrm{m}$ と大きく多孔質だ が, $175^{\circ} \mathrm{C}$ では結晶が著しく微細化し, 粒径は $0.2 \mu \mathrm{m}$
以下である。また，それ以上の温度では再び結唱の成長 がみられるが，緻密である点で $150^{\circ} \mathrm{C}$ の場合之は異な っている。な拉，XRD ではいずれの温度で形成した皮 膜にも $\mathrm{Fe}_{3} \mathrm{O}_{4}$ が検出された。また，XPS に上り皮膜最 外表面に打ける酸素の存在状態を調べたとこる， $\mathrm{H}_{2} \mathrm{O}$, $\mathrm{OH}^{-}$及び $\mathrm{O}^{2-}$ のピーク強度はいずれる温度による变化

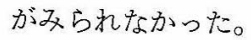

\section{2 実炉水中での温度依存性 (長期)}

304 及び $316 \mathrm{~L}$ 鋼を $130 \sim 280^{\circ} \mathrm{C}$ の炉水に $6,000 \mathrm{~h}$ 浸 漬した場合に，表面に蓄積した ${ }^{60} \mathrm{Co}$ の量及び酸化皮膜 量を Fig. 8 に示す。130 240 ${ }^{\circ} \mathrm{C}$ の温度領域に抢少值 は, 304 鋼を $1,900 \mathrm{~h}$ 浸漬した結果を $6,000 \mathrm{~h}$ まで外そ らして求めたるのでする。な推外そらは $1,900 \mathrm{~h}$ までの 值がいずれる対数則にしたがった増加を示ず施ことに基 づいて行った。また，250 280 ${ }^{\circ} \mathrm{C}$ に扮ける值は $316 \mathrm{~L}$ 鋼配管での結果で㐫る。結果は ${ }^{60} \mathrm{Co}$ 蓄積量及び酸化皮 膜量がともに $250^{\circ} \mathrm{C}$ に極大值をとり, 高温側では減少 することを示している。なお， $285^{\circ} \mathrm{C}$ の純水中では DO $200 \mathrm{ppb}$ 以上で 304 鋼と $316 \mathrm{~L}$ 鋼の腐食挙動飞差が認 められないこと ${ }^{12)}$,さらに実炋水 $\left(230^{\circ} \mathrm{C}\right.$, DO $150 \sim 170$ $\mathrm{ppb})$ 中での ${ }^{60} \mathrm{Co}$ 蓄積挙動にも差がなかったこと1)から, DO 約 $200 \mathrm{ppb}$ の高温純水中では 304 鋼と $316 \mathrm{~L}$ 鋼は 同等に扱光るものと考光られる。

次に，酸化皮膜の組成，形態について調べた。Fig. 9 は内層酸化皮膜中のニッケルとクロムの組成比率を温度 に対してプロットした結果である。な秥ニッケルの值 は $240^{\circ} \mathrm{C}$ 以下については $1,580 \sim 1,900 \mathrm{~h}$ 浸漬した 304 鋼で得られたものをまた $250 \sim 280^{\circ} \mathrm{C}$ とついては $6,000 \mathrm{~h}$ 浸漬した $316 \mathrm{~L}$ 鋼の結果を,さらに $288^{\circ} \mathrm{C}$ に ついてはプラント実配管 (304 鋼) の結果3)をとっだ。な 特，内層酸化皮膜とは超音波洗淨により密着性の悪い外 層を取り除いたのちの残留皮膜を指している。一般に外

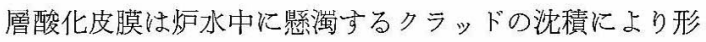
成されるものと考觉られている の比較には内層皮膜を用いることが良いと思われる。結

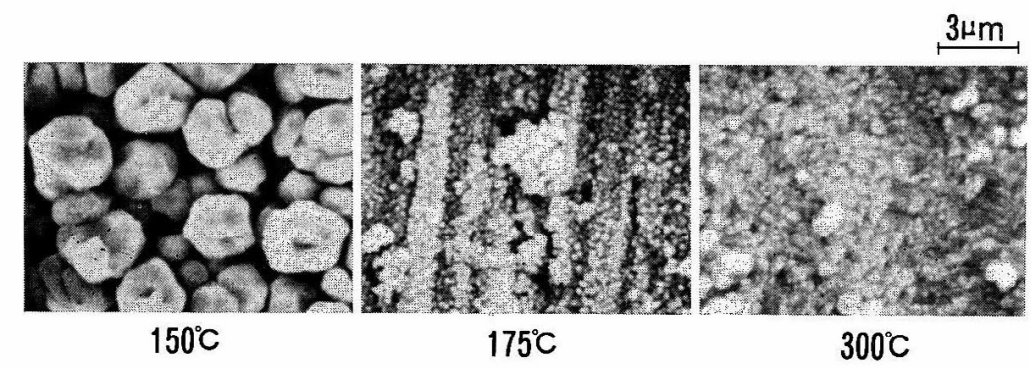

Fig. 7 Scanning electron micrographs of oxide films formed on carbon steel exposed at different temperatures for $90 \mathrm{~h}$. 


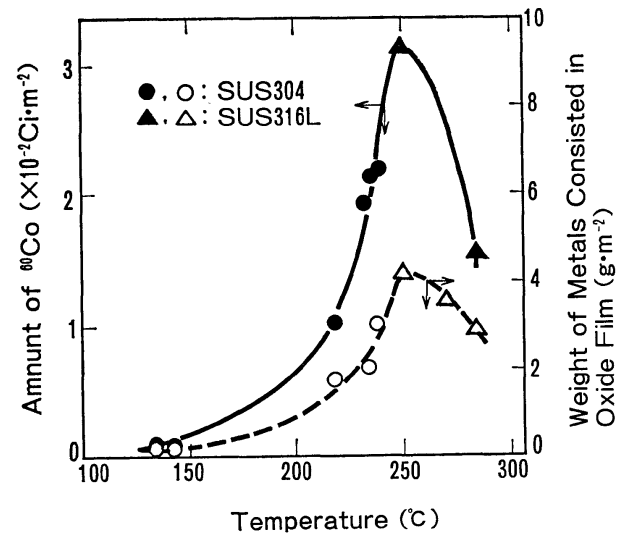

Fig. 8 Effect of temperature on growth of oxide films and deposition of ${ }^{80} \mathrm{Co}$ on stainless steel exposed in reactor water for $6,000 \mathrm{~h}$.

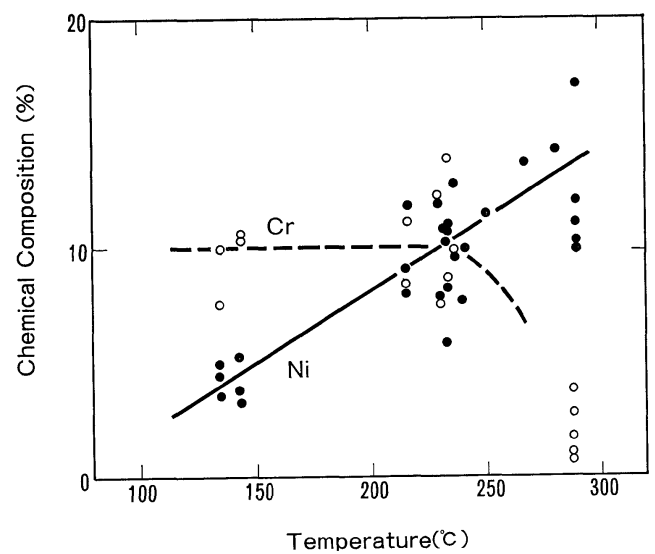

Fig. 9 Effect of temperature on chemical composition of inner oxide films on stainless steel exposed in reactor water.

果をみると、ニッケルの組成比率は浸漬時間によらず温 度の上昇とともに増加傾向を示し, プラント実配管では

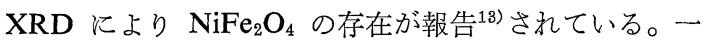
方, クロムの組成比率は浸漬時間に依存して打り時間と ともに減少したが, $130 \sim 240^{\circ} \mathrm{C}$ の範囲で $1,580 \sim 1,900$ $\mathrm{h}$ 浸漬した試料では約 $10 \%$ で温度依存性がなかった。 しかし，長期に炉水にさらされたプラント実配管では, 1〜4\%3) の低い值を示している。

Table 1 は異なる温度で形成した酸化皮膜の形態を XRD で調べた結果である。 $230^{\circ} \mathrm{C}$ の結果は 304 鋼を $1,900 \mathrm{~h}$ 浸漬した場合で, 他は $316 \mathrm{~L}$ 鋼を $6,000 \mathrm{~h}$ 浸漬 した場合である。 $230^{\circ} \mathrm{C}$ では主形態である $\alpha-\mathrm{Fe}_{2} \mathrm{O}_{3}$ とと もに $\alpha \mathrm{FeOOH}$ も検出された。しかし, $250^{\circ} \mathrm{C}$ 以上では 一般式 $\mathrm{M}_{3} \mathrm{O}_{4}$ で示されるスピネル型酸化物が主な成分 であった。この酸化物には鉄, クロム, ニッケルの複合 酸化物が含まれると考えられるが, その詳細な形態は同
Table 1 K-ray diffraction of oxide films formed on stainless steel exposed in reactor water at different temperatures.

\begin{tabular}{c|c}
\hline $\begin{array}{c}\text { Temperature } \\
(\mathrm{C} C)\end{array}$ & $\begin{array}{c}\text { Crystallographic Phases } \\
\text { Major } \\
\text { Minor }\end{array}$ \\
\hline 230 & $\alpha-\mathrm{Fe}_{2} \mathrm{O}_{3}, \alpha-\mathrm{FeOOH}$ \\
\hline 250 & $\mathrm{M}_{3} \mathrm{O}_{4}{ }^{(1), \alpha-\mathrm{Fe}_{2} \mathrm{O}_{3}}$ \\
\hline 265 & $\mathrm{M}_{3} \mathrm{O}_{4}{ }^{(1), \alpha-\mathrm{Fe}_{2} \mathrm{O}_{3}}$ \\
\hline 280 & $\mathrm{M}_{3} \mathrm{O}_{4}{ }^{(1), \alpha-\mathrm{Fe}_{2} \mathrm{O}_{3}}$ \\
\hline \hline
\end{tabular}

(1) $\mathrm{M}_{3} \mathrm{O}_{4}=\mathrm{Fe}_{3} \mathrm{O}_{4}, \mathrm{Ni}(\mathrm{Fe}, \mathrm{Cr})_{2} \mathrm{O}_{4}$,

$(\mathrm{Ni}, \mathrm{Cr}, \mathrm{Fe})_{3} \mathrm{O}_{4}$

定できなかった。

\section{4. 考察}

高温純水中でステンレス鋼の腐食速度が温度に対して 極大をもつ現象はいくつか報告されている。前川委によ ると, DO $100 \mathrm{ppb}$ 以下の脱気静水中では 304 鋼をエメ リ一紙で研磨した試料で $300^{\circ} \mathrm{C}$ に，また酸洗した試料 では $350^{\circ} \mathrm{C}$ に腐食速度の極大が現れた。伊藤 ${ }^{9}$ は DO $50 \sim 400 \mathrm{ppb}$ の流動水中で, 電解研磨した試料が $250^{\circ} \mathrm{C}$ に極大をもつことを報告している。ステンレス鋼の腐食 にともなら現象としては, 腐食生成物の放出と酸化皮膜

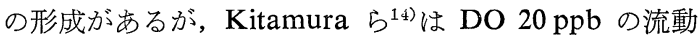
水中でコバルトの放出速度を調べ，これにも $240^{\circ} \mathrm{C} に$ 極大值があることを認めている。本研究の結果は酸化皮 膜量にも同様の傾向があることを示して抢り，腐食にと もならいずれの現象も $240 \sim 350^{\circ} \mathrm{C}$ の高温領域で極大を とることが明らかになった。な拉，この現象は DO が $\mathrm{ppm}$ と高い静水中では観察されない(8)ことから, 比較 的, 低 DO の場合に起こるようである。

304 鋼の初期の腐食速度は温度とともに増大した。し たがって，長期浸漬の場合に高温で腐食が抑制される現 象は，皮膜の保護性に起因するものと考えられる。皮膜 内でのニッケルとクロムの分布は約 $250^{\circ} \mathrm{C}$ を境として 異なり, 低温側ではクロムが比較的安定に存在し, ニッ ケルが溶出するが, 高温側ではクロムが溶出し, ニッヶ ルが安定化している。したがって, 高温では腐食にとも なって鉄及びニッケルイオンが皮膜/金属界面ですみや かに析出し ${ }^{6)}$ ，ポロシティの小さい保護皮膜を形成する ことが，長期浸漬の場合に腐食を抑制する原因と推定さ れる。同様の現象は Castle ら ${ }^{15)}$ が炭素鋼で観察してい る。高温のアルカリ水中で腐食させた炭素鋼を純水中に 


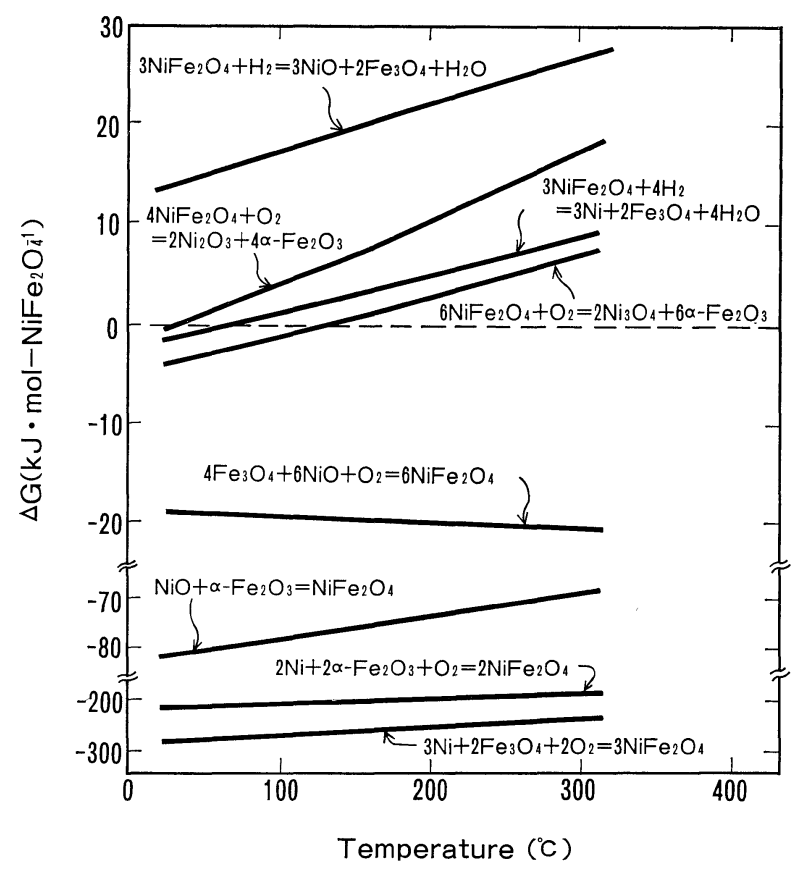

Fig. $10 \Delta G-T$ diagram of reactions in $\mathrm{Fe}-\mathrm{Ni}-\mathrm{O}-\mathrm{H}$ system.

浸漬したところ, 皮膜/金属界面で皮膜の 細孔が閉塞さ れた。これは純水中で鉄酸化物の溶解度が減少したため であろうと推定している。したがって, 酸化物の溶解度 が小さい環境条件では, 腐食反応により生成した金属イ オンは皮膜/金属界面で直ちに酸化物を形成するため, 皮膜は緻密化し保護性を増すために腐食を抑制するもの と考えられる。

そこで, $\mathrm{Ni}-\mathrm{Fe}-\mathrm{O}-\mathrm{H}$ の 4 元素に和ける各種反応の熱 力学的な安定性を調べた。Fig. 10 は Rummery ら ${ }^{16)}$ 結果を BWR 炉水条件である酸素 $200 \mathrm{ppb}$, 水素 $4 \mathrm{ppb}$ で計算し直したものである。いずれの反応にも $\mathrm{NiFe}_{2} \mathrm{O}_{4}$ が関与しているが，午の生成反応は室温から $300^{\circ} \mathrm{C}$ ま での温度領域で非常に起こりやすいことがわかる。一 方, 酸素あるいは水素によって他の酸化物に変わる反応 は， $150^{\circ} \mathrm{C}$ 以上ではいずれも自由エネルギー变化 $(\Delta G)$ が正で起こりにくく, この 4 元素系に拈いては高温で $\mathrm{NiFe}_{2} \mathrm{O}_{4}$ が最も安定な酸化物として存在することがわ かる。な拉, 酸化性雾囲気に执いては, 高温でニッケル が皮膜を安定化させることがステンレス鋼の耐食性を高 める原因であることは, 高温汇打ける304 鋼の耐食性が ニッケルを含まないフェライト系ステンレス鋼 $(17 \mathrm{Cr}$ 鋼)上りる優れている日゙ことからも妥当と考兄られる。

ところで, XPS 及び XRD の結果によると, 低温で 形成した 304 鋼の皮膜は, 高温で形成した皮膜よりも $\mathrm{OH}^{-}$基の存在比率が高い。これはクロムを含まない炭 素鋼の皮膜では $\mathrm{O}^{2-}$ 基及び $\mathrm{OH}^{-}$基の存在比率に温度依
存性がないことから，皮膜中のクロム濃度が低温で高く なることと無関係ではないようである。また，Fig. 4 亿 示した $577 \mathrm{eV}$ の $\mathrm{Cr} 2 \mathrm{p}_{3 / 2}$ のピークが $\mathrm{Cr}^{3+}(577.1 \mathrm{eV})^{17)}$ とよく一致していることを考光併せると，低温ではク口 ムは $\mathrm{CrOOH}$ あるいは $\mathrm{Cr}(\mathrm{OH})_{3}$ として皮膜中に安定に 存在するものと推定される。な叔, Okamoto ${ }^{18)}$ は室温 に和汀るステンレス鋼の不働態皮膜を検討し, 耐食性の 原因が新たに生成した金属イオンをプロトンの引き抜き を伴いながら結合する役割を果たす結合水の㗢きにある と推定した。本研究の結果はさらに, 約 $250^{\circ} \mathrm{C}$ 以下の 低温領域でステンレス鋼の耐食性が炭素鋼よりも優れて いる原因が，皮膜のクロム濃度の増加により緩衝作用の 大きい $\mathrm{OH}^{-}$基の存在比率が高くなることにあることを 示唆している。

ところで, 腐食速度が極大を示す現象は炭素鋼でも報 告されているが，その温度はステンレス鋼の場合に比べ ると相当低い。Brush ら $5^{10)}$ が DO 15 30 ppb の純水中 に扣いて $38 \sim 204^{\circ} \mathrm{C}$ の範囲で調べた結果では, 約 $100^{\circ} \mathrm{C}$ に極大值が現れた。また, $150 \sim 300^{\circ} \mathrm{C}$ で検討し た本研究では, $150^{\circ} \mathrm{C}$ で腐食量が最大值を示した。ステ ンレス鋼との温度の違いは金属組成の差にあろうが，こ

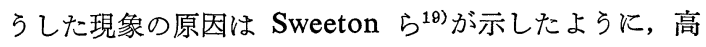
温で $\mathrm{Fe}_{3} \mathrm{O}_{4}$ の溶解度が減少し, それによって皮膜の保護 性が向上する点にあると考元られる。これはSEM 観察 の結果からすらかがえることであり, 原因の本質はステ ンレス鋼の場合と似たところにあると思われる。 


\section{5. 結 言}

BWR プラント炉水環境である酸素を溶存した純水中 に护ける 304，316L 鋼及び炭素鋼に及ぼす温度の影響 を $150 \sim 300^{\circ} \mathrm{C}$ の範囲で検討した結果, 次の結論を得 た。

（1）オーステナイト系ステンレス鋼の酸化皮膜は， 約 $250^{\circ} \mathrm{C}$ を境化化学組成と形態が変化する。低温では ニッケルが溶出し, クロムは比較的安定であり, 皮膜中 の $\mathrm{OH}^{-}$基が増す。したがって，この温度領域での耐食 性が炭素鋼より勝るのは, 皮膜中に $\mathrm{Cr}(\mathrm{OH})_{3}$ あるいは $\mathrm{CrOOH}$ が安定に存在するためと推定される。一方, 高 温では逆にクロムが溶出し、ニッケルは $\mathrm{NiFe}_{2} \mathrm{O}_{4}$ を形 成して皮膜の保護性を増す。このため長期浸漬後の腐食 速度は約 $250^{\circ} \mathrm{C}$ に極大をとり, 放射性コバルトイオン の蓄積にも同様の現象を生じる。

（2）炭素鋼は $90 \mathrm{~h}$ 浸漬では $150^{\circ} \mathrm{C}$ で腐食が著し い。温度の上昇は皮膜を緻密化して放出量を減少させ， $200^{\circ} \mathrm{C}$ で腐食量が最小となる現象が現れる。また，皮膜 は主に $\mathrm{Fe}_{3} \mathrm{O}_{4}$ で構成され，温度による形態变化はない。

おわりに，実炉水浸漬実験に際し，多大の御尽力を頂 いた中国電力株式会社，米沢鴻一氏，合田隆一氏に厚く 謝意を表します。

(Received March 20, 1987)

\section{文献}

1) T. Honda, M. Izumiya, A. Minato, K. Ohsumi \& H. Matsubayashi: Nucl. Technol., 64, 35 (1984).

2) T. Honda, A. Minato, K. Ohsumi \& H. Matsubayashi: Nucl. Technol., 65, 438 (1984).

3) G. Romeo: Proc. 7th Int. Congress Metallic Corrosion, 3, 1456 (1978).
4) T. Honda, K. Ohashi, Y. Furutani, Y. Sato \& H. Mochizuki: Water Chemistry for Nuclear Reactor Systems 4, paper 45, British Nucl. Energy Soc., Bournemouth (1986).

5) C. C. Lin, C. R. Pao, J.S. Wiley \& W. R. DeHollander: Water Chemistry for Nuclear Reactor Systems 2, paper 46, British Nucl. Energy Soc., Bournemouth (1980).

6）本田 卓, 樫村栄二, 大橋健也, 古谷保正：防食 技術, 36, 267 (1987).

7) M. Warzee, J. Hennaut, M. Maurice, C. Sonnen, J. Waty \& Ph. Berge: J. Electrochem. Soc., 112, 670 (1965).

8）前川立夫, 香川 優, 中島宣雄：日本金属学会誌, 31, 1213 (1967).

9）伊藤伍郎，清水義彦，佐藤俊司：防食技術， 18, 345 (1969).

10) E. G. Brush \& W.L. Pearl: Corrosion, 28, 129 (1972).

11) M. Datta, H. J. Mathieu \& D. Landolt: J. Electrochem. Soc., 131, 2484 (1984).

12）本田 卓, 大橋健也, 樫村栄二, 古谷保正：腐食 防食'87 講演集, C-108 (1987).

13) L. D. Anstine: NEDE-12665, General Electric Co. (1977).

14) M. Kitamura, Y. Ozawa \& S. Uchida: Int. Symp. on Environmental Degradation of Materials in Nuclear Power System-Water Reactor, Paper 22, Sowth Carolina (1983).

15) J. E. Castle \& H. G. Masterson: Corros. Sci., 6, 93 (1966).

16) T. E. Rummery \& D. D. Macdonald: $A E C L$ 4577, Atomic Energy of Canada Limited (1973).

17）杉本克久, 岸 興作, 池田重良, 沢田可信：日本 金属学会誌, 38, 54 (1974).

18) G. Okamoto: Corros. Sci., 13, 471 (1973).

19) F. H. Sweeton \& C. F. Baes, Jr.: J. Chem. Thermodynamics, 2, 479 (1970). 